\title{
A GYÁRTÁS KÖZBEN ALKALMAZOTT HƯTÉS HATÁSA HŐÁLLÓ PLA-ALAPANYAGRA
}

\section{THE IMPACT OF ACTIVE COOLING ON HEAT RESISTANT PLA}

\author{
Lukács Norbert László, ${ }^{1}$ Ficzere Péter, ${ }^{2}$ Szebényi Gábor ${ }^{3}$ \\ Budapesti Müszaki és Gazdaságtudományi Egyetem, Budapest, Magyarország \\ ${ }^{1}$ lukacsnorbert98@gmail.com \\ 2ficzere@kge.bme.hu \\ ${ }^{3}$ szebenyi@pt.bme.hu
}

\begin{abstract}
In this study the properties of HT-PLA were determined with tensile tests. The influence of cooling was determined and influence of manufacturing environment shown to be predictable. Heat resistant 3D printing materials can be widely used in the manufacturing process but these materials are relatively expensive. HTPLA is one of the cheapest materials with these parameters.
\end{abstract}

Keywords: FDM, high temperature PLA, additive manufacturing, 3D printing, cooling.

\section{Összefoglalás}

Ezen tanulmányban a HT-PLA fantázianevű hőálló PLA-anyag tulajdonságait vizsgáltuk hagyományos szakítóvizsgálattal. A vizsgálat segítségével megismertük a tárgyhűtés hatását az alkatrész tulajdonságaira, és következtetéseket tudtunk levonni a környezet hatásáról a munkadarabra. A hőálló filamentek széles körben használhatóak a gyártási folyamatok során, azonban gyakran nagyon magas ár jellemzi őket. A HT-PLA az egyik legolcsóbb olyan anyag, amely elméletileg akár $100^{\circ} \mathrm{C}$ elviselésére is képes.

Kulcsszavak: FDM, additív gyártástechnológiák, 3D nyomtatás, hőálló alapanyagok, hütés.

\section{Bevezető}

Az FDM-technológia terjedésével a felhasználási területek is változnak, egyre több ilyen módon gyártott alkatrész kerül közvetlen felhasználásra [1]. Mára már számtalan típusú alapanyag áll rendelkezésünkre, van köztük hőálló, flexibilis, UV-álló is. Az alapanyagok egy új fajtája a hőkezelhető filamentek csoportja, mely könnyebbé teszi a gyártást és számunkra megfelelő anyagtulajdonságokat biztosít, azonban az utólagos hőkezelés egyéb várható kellemetlenségeket okozhat, köztük a vetemedést, illetve méretváltozást is. Ebben a tanulmányban a gyártás során alkalmazott hütés hatását tárgyaljuk, azonban a jövőben a hőkezelés hatásait is vizsgáljuk.

\section{Módszer}

„A HT-001-ből nyomtatott alkatrészek eleve a hagyományos PLA-nál magasabb hőállósággal rendelkeznek (65-70 ${ }^{\circ} \mathrm{C}$ HDT érték E2092 szabvány szerint). Ezt az értéket könnyen $100^{\circ} \mathrm{C}$ fölé növelhetjük egy rövid hőkezelés elvégzésével:

A kinyomtatott tárgyat helyezzük előmelegített kemencébe (sütőbe) 20 perc időtartamra, 80-100 ${ }^{\circ} \mathrm{C}$-os hőmérséklet mellett, majd óvatosan hagyjuk lehülni. A polimerszerkezet az eljárás során kristályrácsba rendeződik, mely magasabb hőállóságot és szilárdságot eredményez [2].”

A gyártáshoz egy CrealityEnder 3 nyomtatót használtunk fel, mely egy egyszerü, kereskedel- 
mi forgalomban kapható, bárki számára elérhető áru FDM (FFF) 3D-nyomtató.

A próbatesteket fekvő, valamint álló helyzetben is kinyomtattuk hütés alkalmazásával, majd anélkül is (1. ábra). A gyártási paraméterek:

$-215^{\circ} \mathrm{C}$-os fej-, illetve $60{ }^{\circ} \mathrm{C}-$ os asztalhőmérséklet; $-40 \mathrm{~mm} / \mathrm{s}-$ os sebesség;

-100\%-os belső kitöltöttség;

- a rétegvastagság $0,2 \mathrm{~mm}$.

Ezeket az adatokat több korábbi tanulmány is a legmegfelelőbb általános paramétereknek jelölte meg PLA-nyomtatás során [3, 4, 5]. A próbatestek szakítóvizsgálata a BME Polimertechnika tanszék Zwick Z005-ös berendezésén történt (2. ábra).

Minden esetben 5-5 szabványos próbatestet vizsgáltunk. A szakítási sebesség szabvány szerint $5 \mathrm{~mm} / \mathrm{s}$ volt (3. ábra).

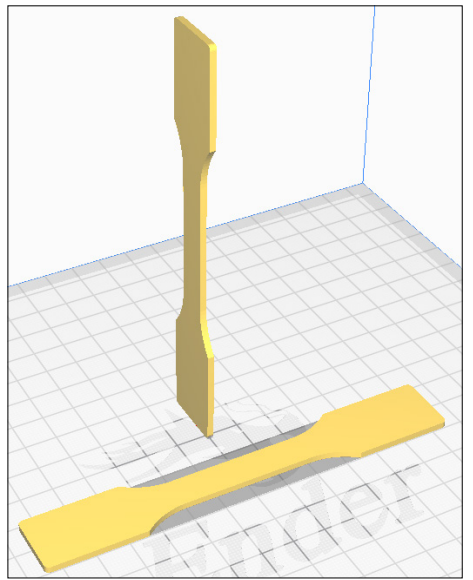

1. ábra. Szabványos próbatestek

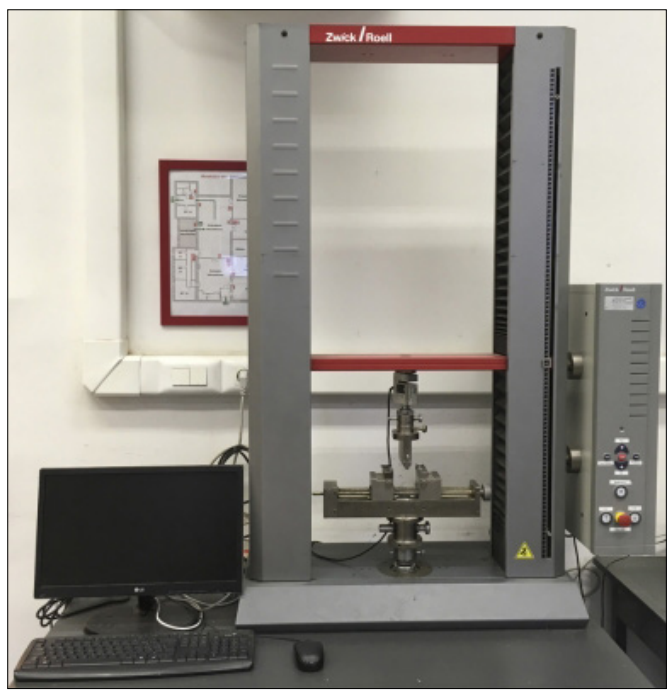

2. ábra. Zwick Z005 mérőberendezés

\section{Eredmények}

A fekvő helyzetben nyomtatott próbatestek szakítóvizsgálatainak eredményeit a következő diagramok szemléltetik. Mint látható, a hűtés nélkül gyártott próbatestek szakítószilárdsága átlagosan körülbelül $45 \mathrm{MPa}$ (4. ábra) volt, ami jelentősen eltér a gyártó által megadott $66 \mathrm{MPa}$ értéktől. Ez önmagában adódhat a nyomtatás során alkalmazott kitöltés irányából [6], valamint a nem megfelelő szálak közti tapadásból [4]. A gyártó nem ad meg irányfüggést.

Az aktív hűtéssel gyártott próbatestek szakítószilárdsága jelentősen csökkent a hűtés nélkül gyártott próbatestekéhez képest (5. ábra). Mint látható, a szakítószilárdságuk nem sokkal nőtt 35 MPa fölé.

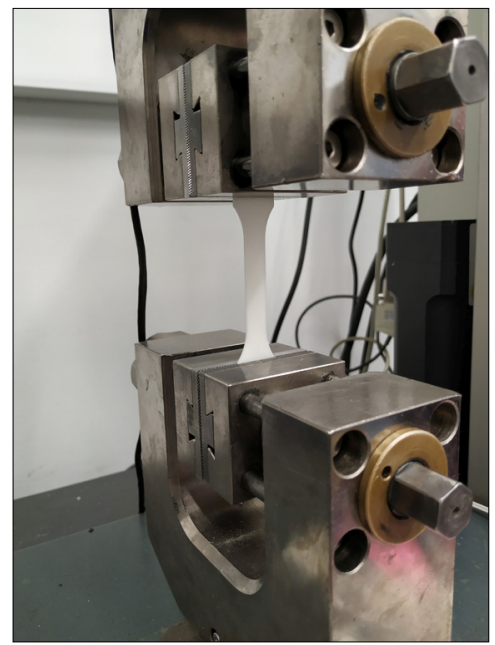

3. ábra. Próbatestek vizsgálata

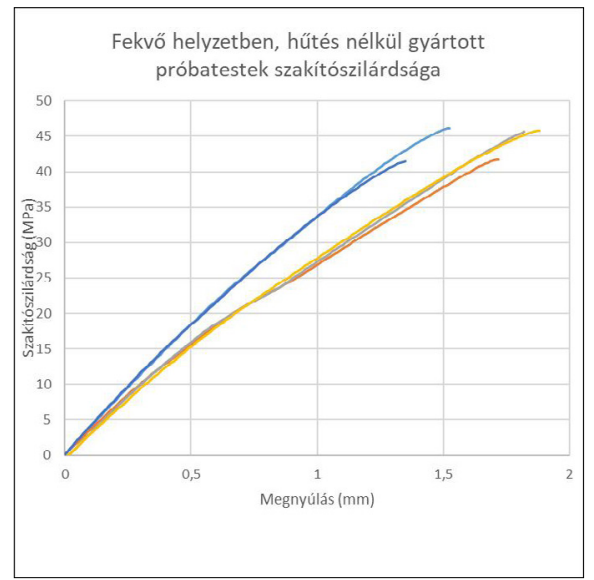

4. ábra. Fekvő helyzetben, hütés nélkül gyártott próbatestek szakítószilárdsága 


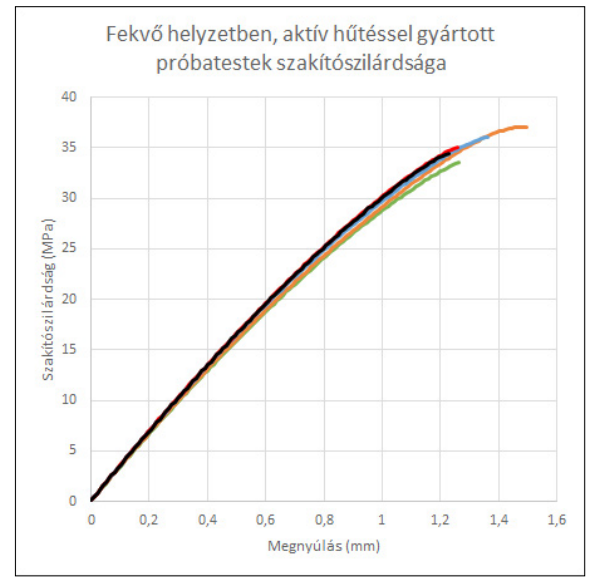

5. ábra. Fekvő helyzetben, aktív hütéssel gyártott próbatestek szakítószilárdsága

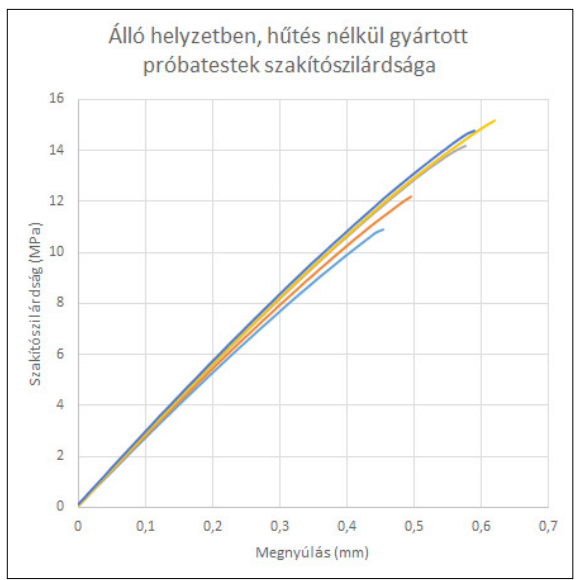

6. ábra. Álló helyzetben, hütés nélkül gyártott próbatestek szakítószilárdsága

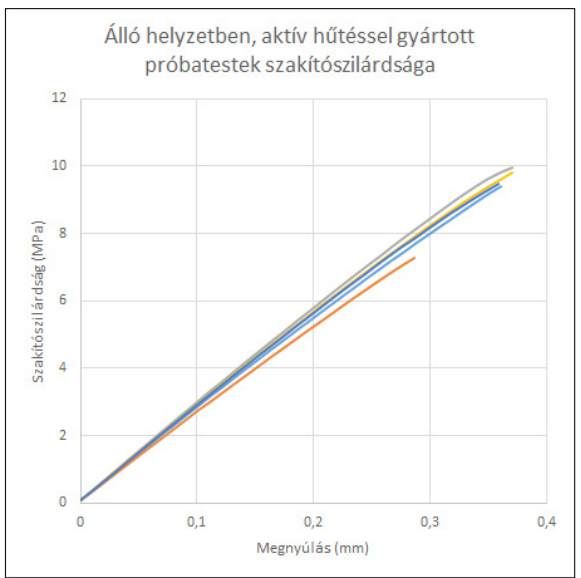

7. ábra. Álló helyzetben, aktív hütéssel gyártott próbatestek szakítószilárdsága
A hűtés alkalmazása sok esetben elengedhetetlen az FDM-nyomtatás során, különösen a nagy túllógásokkal tűzdelt alkatrészek esetében, ahol szükséges az anyag mielőbbi megszilárdulása a megfelelő felületminőség eléréséhez.

Az álló helyzetben gyártott próbatestek mechanikai tulajdonságai nem érték el a korábbi eredmények alapján várt értékeket [7], azonban az aktív hűtés nélkül gyártott próbatestek ebben az esetben is jobb tulajdonságokat mutattak.

Az aktív hütéssel gyártott, állított próbatestek szakítódiagramjai a 7. ábrán figyelhetők meg.

Az eredmények táblázatos formában:

1. táblázat. A próbatestek átlagos szakítószilárdságai

\begin{tabular}{|l|c|}
\hline \multicolumn{1}{|c|}{ Próbatest típusa } & $\begin{array}{c}\text { Átlagos szakítószilárdsága } \\
\text { (MPa) }\end{array}$ \\
\hline Fekvő, hűtéssel & 35,21 \\
\hline Fekvő, hűtés nélkül & 44,23 \\
\hline Álló, hűtéssel & 9,18 \\
\hline Álló, hűtés nélkül & 13,44 \\
\hline
\end{tabular}

\section{Következtetések}

A vizsgálatok alapján elmondható, hogy a hütés hatására jelentősen csökkent a próbatestek szakítószilárdsága - az átlagos 44 MPa-ról körülbelül 35 MPa-ra, ami körülbelül 20\%-os csökkenést jelent - így az FDM-technológiával előállítani kívánt alkatrészeket ajánlott úgy megtervezni, hogy azok ne igényeljenek hűtést. Ezt a jelenséget magyarázhatja az, hogy hűtés hatására a fúvóká-

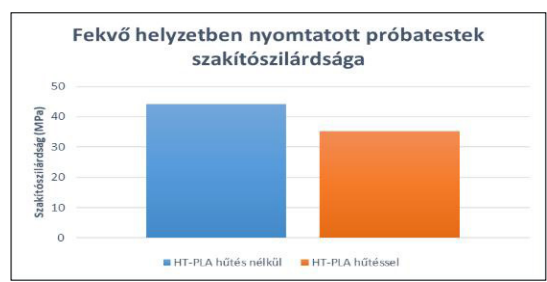

8. ábra. A fekvő helyzetben gyártott próbatestek összehasonlítása

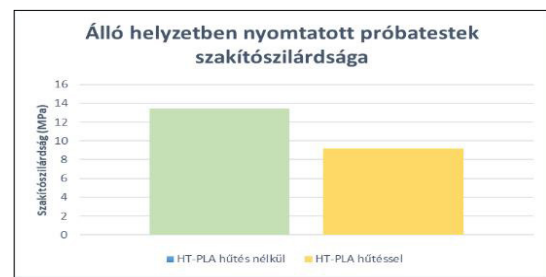

9. ábra. Az álló helyzetben gyártott próbatestek összehasonlítása 
ból kiáramló anyag már azelőtt elkezd megszilárdulni, hogy összeolvadna az előző rétegekkel (8. ábra).

Az álló próbatestek esetében ez az arány tovább romlott, itt már körülbelül 30\%-ra tehető a különbség a hütve, illetve a hütés nélkül gyártott darabok esetében (9. ábra).

\section{5. Összefoglalás}

A kapott eredmények alapján könnyen megállapíthatjuk a tárgyhütés negatív hatását az FDM-technológiával gyártott alkatrészek mechanikai tulajdonságaira. Az eredmények ismeretében fontos az így készítendő tárgyakat, alkatrészeket úgy tervezni, hogy azok ne igényeljenek hűtést a nyomtatás során. A jövőbeni felhasználás előtt a hőkezelés anyagra gyakorolt hatásait, valamint az alkatrész formai követelményeire gyakorolt hatásait is szükséges megvizsgálni.

\section{Köszönetnyilvánítás}

Ez a tanulmány nem jöhetett volna létre Dr. Török Ádám közreműködése nélkül. Köszönjük a munkáját!

\section{Szakirodalmi hivatkozások}

[1] Gerendás P., Károly D., Pammer D., Kiss R. M.: Egyedi kézrögzítő fejlesztés és gyártása $3 D$ nyomtatással. Biomechanica Hungarica XI/2., 23-30.

[2] 3DEE Store Budapest (letöltve: 2020.01.28.) https://3dee.hu/termek/ht-pla-001/

[3] Lukács N. L., Ficzere P., Temesi T.: Gyártási paraméterektől függö rétegközi hibák vizsgálata $C A D$ szoftverekkel. GÉP, LXX/3, 54-57.

[4] Ogjan L. et all.: Impact of processing parameters on tensile stength in-process crysallinity and mesostructure in FDM-fabricated PLA specimens. Rapid Prototyping Journal 25/8. (2019) 1398-1410

[5] Ficzere P., Lukács N. L.: Evaluation opportunities of SEM pictures by CAD software. Design of Machines And Structures 9/2. (2019) 20-24.

[6] K. Álvarez C., Lagos R. F., Aizpun M. : Investigating the influence of infill percentage on the mechanical properties of fused deposition modelled ABS parts. Ingeniería e Investigación 36/3. (2016) 110-116. https://doi.org/10.15446/ing.investig.v36n3.56610

[7] Ficzere P., Borbas L., Falk Gy., Szebenyi G.: Experimental determination of material model of machine parts produced by Selective laser sintering (SLS) technology. Materials Today: Proceedings, 5/13. Part 2, (2018) 26489-26494. https://doi.org/10.1016/j.matpr.2018.08.104. 